\title{
Investigation of visual loss: neuro-ophthalmology from a neurologist's perspective
}

\author{
Christian J Lueck
}

A large proportion of the human nervous system is devoted to receiving and processing visual information. ${ }^{1}$ This means that the potential for CNS disease to produce visual disturbance of one sort or another is enormous. The great advantage to the clinician dealing with a visual disturbance is that the visual pathways are organised very precisely, with preservation of topographic relation from retina through optic nerves, chiasm, tracts, geniculate nuclei, radiations, and on into the visual cortex. ${ }^{2}$ Hence, careful attention to visual field disturbance is likely to give a fairly precise clue as to what part of the visual system is being affected.

Because certain diseases are more likely to affect some parts of the visual system than others, it is often possible to narrow down a differential diagnosis simply on the basis of site of lesion. This process of restricting the differential is further enhanced by knowing the time course over which visual disturbance has developed. These two considerations make the investigation of such disturbances much more straightforward.

\section{Differential diagnosis of visual loss}

Visual loss has a wide differential diagnosis (table 1). Visual loss secondary to trauma, or longstanding, non-progressive visual loss (for example, amblyopia), ${ }^{23}$ is not considered further here; nor is visual loss secondary to diseases of the eye itself, to visible disturbance of the retina, or secondary to psychogenic causes. ${ }^{4}$

\section{VISUAL FIELD LOSS}

Assessment requires accurate visual fields. ${ }^{5}$

\section{Retinaloptic disc}

Ophthalmoscopically visible lesions of the retina or choroid are likely to produce focal scotomatous field loss. Patterns of visual field loss likely to be encountered by a neurologist and referable to disorders of the retina or optic disc include central visual field loss (macular lesion), concentric visual field loss, sectoral visual field loss, altitudinal field loss, and arcuate scotomata. Bilateral macular sparing homonymous hemianopias may masquerade as bilateral concentric field reduction. There is usually a small step at the vertical meridian if visual fields are performed carefully.

\section{Optic nerveldisc}

Although the classic pattern of visual field loss is a central scotoma, optic nerve disease can give rise to various field defects including arcuate scotoma, centrocaecal scotoma, paracentral scotoma, and altitudinal field defects. The pattern of monocular visual field loss is of limited utility in distinguishing one disease from another. ${ }^{6}$ Swelling of the optic nerve head may give rise to an enlarged blind spot.

\section{Optic chiasm}

Compression of the central chiasm typically gives rise to a bitemporal hemianopia. There are, however, considerable variations on this, including bitemporal partial field defects (which may be considerably asymmetric), and junctional scotomata. It is important to examine the upper temporal visual field of the "good eye" in a patient presenting with apparent unilateral visual loss. A binasal visual field defect has been reported to occur with sideways compression of the chiasm (in theory picking out the uncrossed fibres of each side), but this is rare. ${ }^{7}$ Damage to the whole optic chiasm will, of course, give rise to total bilateral visual field loss.

\section{Retrochiasmal lesions}

Congruity of homonymous defects tends to increase as the lesion becomes more posterior, but this is by no means an absolute rule. Lateral geniculate lesions tend to give rise to "wedge hemianopias". Lesions in the optic radiation can give rise to homonymous upper or lower quadrantanopias. Occipital lobe lesions typically produce congruous hemianopias which may or may not be macular sparing. If the lesion in the occipital lobe is very posterior, it may spare the cortical representation of the far lateral visual field, thereby producing sparing of the temporal crescent of the contralateral eye.

\section{TIME COURSE}

The temporal evolution of visual loss may be divided into four groups: transient (reversible), irreversible onset over seconds/minutes, progressive onset over hours/days, or progressive onset over days to months or longer.

It may be difficult to be confident in allocat-
Department of Clinical Neuroscience, Western General Hospitals rust, Crewe Road, 
Table 1 Differential diagnosis of visual loss based on site and timing of lesion

\begin{tabular}{|c|c|c|c|c|}
\hline Site of lesion & Transient & Seconds to minutes & Hours to days & Days to months + \\
\hline Retinal & $\begin{array}{l}\text { Amaurosis fugax: } \\
\text { Thromboembolic } \\
\text { Benign (young) } \\
\text { Retinal migraine } \\
\text { Photostress (ischaemia) } \\
\text { Hemeralopia (dystrophies) } \\
\text { Angle closure glaumoma }\end{array}$ & $\begin{array}{l}\text { CRAO/BRAO } \\
\text { CRVO/BRVO }\end{array}$ & $\begin{array}{l}\text { "Phlebitis" } \\
\text { Ischaemia }\end{array}$ & $\begin{array}{l}\text { Macular degenerations } \\
\text { Hereditary retinal disease: } \\
\text { Retinitis pigmentosa } \\
\text { Cone/rod dystrophies } \\
\text { Storage disorders } \\
\text { Neurodegenerative conditions } \\
\text { Uveomeningeal syndromes } \\
\text { Carcinoma associated retinopathy }\end{array}$ \\
\hline $\begin{array}{l}\text { Optic nerve/ } \\
\text { optic disc }\end{array}$ & $\begin{array}{l}\text { AION (vasculitic) } \\
\text { Obscurations } \\
\text { (papilloedema) }\end{array}$ & $\begin{array}{l}\text { Abnormal fundus: } \\
\text { AION: } \\
\text { Vasculitic } \\
\text { Non-vasculitic } \\
\text { Leber's HON } \\
\text { Disc haemorrhage } \\
\text { Diabetic papillopathy } \\
\text { Big blind stop syndrome } \\
\text { Neuroretinitis } \\
\text { Optic nerve head drusen } \\
\text { Normal fundus: } \\
\text { PION } \\
\text { (compressive lesion) }\end{array}$ & $\begin{array}{l}\text { Typical ON } \\
\text { Atypical ON: } \\
\text { Immune } \\
\text { Infective } \\
\text { Leber's HON } \\
\text { Neuroretinitis } \\
\text { Paraneoplastic } \\
\text { Toxic }\end{array}$ & $\begin{array}{l}\text { Compressive: } \\
\text { Neoplasm } \\
\text { Thyroid eye disease } \\
\text { Aneurysm } \\
\text { Granuloma } \\
\text { Paget's disease } \\
\text { Infective/inflammatory: } \\
\text { Syphilis } \\
\text { HTLV 1 (TSP) } \\
\text { Tuberculosis } \\
\text { Orbital/paranasal sinus infection } \\
\text { Sarcoidosis } \\
\text { Leber's HON } \\
\text { Infiltrative } \\
\text { Toxic/nutritional (B12) } \\
\text { Hereditary neuropathy } \\
\text { Chronic papilloedema } \\
\text { Post irradiation } \\
\text { AVM } \\
\text { Optic disc dysplasia }\end{array}$ \\
\hline Optic chiasm & $\begin{array}{l}\text { Cystic tumours } \\
\text { Craniopharyngioma } \\
\text { Mucocele }\end{array}$ & $\begin{array}{l}\text { Pituitary apoplexy } \\
\text { Ruptured AVM }\end{array}$ & $\begin{array}{l}\text { Pituitary tumour } \\
\quad \text { (pregnancy) } \\
\text { Pituitary abscess } \\
\text { Sphenoidal abscess } \\
\text { Demyelination } \\
\text { Adenohypophysitis }\end{array}$ & $\begin{array}{l}\text { Compressive: } \\
\text { Neoplasm } \\
\text { Sphenoidal mucocele } \\
\text { Dilated IIIrd ventricle } \\
\text { Granuloma (sarcoid, TB) } \\
\text { Aneurysm } \\
\text { Primary hypothyroidism } \\
\text { Thalassaemia } \\
\text { Postradiation damage } \\
\text { Subacute/chronic meningitis } \\
\text { Septo-optic dysplasia } \\
\text { Empty sella syndrome }\end{array}$ \\
\hline $\begin{array}{l}\text { Retrochiasmal } \\
\text { pathways }\end{array}$ & $\begin{array}{l}\text { TIA } \\
\text { Migraine } \\
\text { Epilepsy } \\
\text { Trauma (children) }\end{array}$ & $\begin{array}{l}\text { CVA: } \\
\text { Thromboembolic } \\
\text { Haemorrhage } \\
\text { (tumour) } \\
\text { Spasm (angiography) } \\
\text { Migraine } \\
\text { Impaired cerebral perfusion }\end{array}$ & $\begin{array}{l}\text { Demyelination } \\
\text { Cerebral abscess } \\
\text { Tumour } \\
\text { Poisoning } \\
\text { Meningitis } \\
\text { Encephalitis }\end{array}$ & $\begin{array}{l}\text { Tumour: } \\
\quad \text { Intrinsic } \\
\text { Extrinsic } \\
\text { AVM } \\
\text { Creutzfeldt-Jakob } \\
\text { Pelizaeus-Merzbacher } \\
\text { Metachromatic leukodystrophy } \\
\text { Progressive multifocal leukoencephalopathy } \\
\text { Subacute sclerosing panencephalitis } \\
\text { Schilder's disease }\end{array}$ \\
\hline
\end{tabular}

AION = anterior ischaemic optic neuropathy; AVM = arteriovenous malformation; BRAO = branch retinal artery occlusion; BRVO = branch retinal vein occlusion; CRAO = central retinal artery occlusion; CRVO = central retinal vein occlusion; CVA = cerebrovascular accident; HON $=$ hereditary optic neuropathy; HTLV 1 = human T lymphocytic virus, type I; ON = optic neuritis; PION = posterior ischaemic optic neuropathy; TB = tuberculosis; TIA = transient ischaemic attack; TSP = tropical spastic paraparesis.

ing the patient's symptoms to one specific group, and more than one differential diagnostic category may therefore have to be considered. A typical example of this would be when a patient awoke with visual loss in one eyethis could have arisen suddenly over seconds to minutes during the night, or, alternatively, have developed over several hours. All possible diagnoses in both groups would then have to be considered.

\section{Investigation of visual loss}

TRANSIENT VISUAL LOSS IN ONE EYE

By definition, the visual fields will be normal in relation to a transient attack. It is therefore crucial to try to determine the nature of the visual field disturbance on the basis of the history. Patients are notoriously unable to tell the difference between visual disturbance in one visual hemifield versus that in one eye (amaurosis fugax), and it can be very difficult to sort this out. Apart from asking the patient whether alternate eye closure was attempted, it is often helpful to ask them what their vision was like during the attack: I usually ask them if, were they to look directly at my face during an attack, would the whole face be normal or would one half of it be affected?

Whether or not the transient visual field loss was referable to the eye or to the occipital cortex, preliminary investigations are similar, looking for causes of transient ischaemic attack. $^{89}$ Such tests include haematological (full blood count, erythrocyte sedimentation rate, clotting) and biochemical (glucose, urea, and electrolytes, cholesterol) blood tests, chest radiography, ECG, and cranial CT. Depending on circumstances, other more specific tests may be indicated. ${ }^{89}$

Carotid ultrasound (Doppler or duplex) examination is appropriate if the visual loss affected one eye, if the patient would entertain the idea of an endarterectomy. The degree of stenosis must be more firmly established with further imaging, such as selective carotid angiography, but some centres are increasingly using MR angiography. ${ }^{9}$

Amaurosis fugax may occasionally be the harbinger of irreversible visual loss in patients with giant cell arteritis. ${ }^{10}$ If there is any suggestion of headache, jaw claudication, or general malaise, an erythrocyte sedimentation rate should be performed as an emergency. If it is 
not raised, but the story is suggestive, strong consideration should be given to temporal artery biopsy because up to $17 \%$ of cases are not associated with raised erythrocyte sedimentation rate. ${ }^{10}$

In young people, recurrent monocular visual loss is often a benign condition, unassociated with an increased risk of stroke. It is probably due to vascular spasm, and may be pathogenetically related to migraine. ${ }^{11}$ It is usually regarded as a diagnosis of exclusion, and only applicable after the above investigations and imaging of the optic nerve or visual pathways have come back negative. ${ }^{11} 12$

Obscurations are transient disturbances of vision which occur in association with papilloedema secondary to raised intracranial pressure of whatever cause. This usually results in bilateral visual symptoms, but if the papilloedema is unilateral, monocular symptoms can result. Typically patients do not lose vision entirely (vision does not go "black"), but complain of greying of vision, often in association with change in posture. In this situation, it is obviously mandatory to image the head (MRI or $\mathrm{CT}^{13}$ ) to look for a cause of raised pressure. If imaging shows no space occupying lesion, lumbar puncture is indicated. There are many causes of a raised CSF pressure in the absence of a space occupying lesion (pseudotumour cerebri), ${ }^{3}$ but one important condition is sagittal sinus thrombosis. Nowadays, this can often be detected by MR angiography, but formal angiography may still be required, depending on local facilities. This condition and its management have been dealt with in a recent editorial in this fournal. ${ }^{14}$

There are a few unusual causes. Ocular ischaemia can present with transient visual loss provoked by exposure to bright light (photostress). There are usually ophthalmoscopic changes to suggest the diagnosis, including peripheral exudates and haemorrhages, microaneurysms, and new vessels. A photostress test $^{3}$ is useful in this circumstance, and further investigation will include carotid ultrasound with tests as for amaurosis fugax. Transient visual disturbance provoked by changes in ambient lighting can also be produced by retinal diseases such as cone dystrophies, and diagnosis can be aided by the use of electroretinography. ${ }^{515}$ Finally, if the diagnosis remains obscure, an attempt should be made to measure intraocular pressure during an attack as acute closed angle glaucoma can rarely present with transient visual loss. ${ }^{16}$

\section{SUDDEN, IRREVERSIBLE VISUAL LOSS IN ONE} EYE

Conditions referable to primary ocular structures such as acute angle closure glaucoma or vitreous haemorrhage will not be discussed here. Nevertheless, it is likely that there will be abnormalities on ophthalmoscopy to aid diagnosis, especially if the patient is seen within a day or so of the acute event. If possible, pupil dilatation should be performed as failure to perform this often results in missing ophthalmoscopic clues to diagnosis. If ophthalmoscopy is completely normal, then the possibility of posterior ischaemic optic neuropathy should be considered, although this condition is rare. ${ }^{2}$

Usually, however, ophthalmoscopy shows changes which suggest a diagnosis, provided the patient is seen within 24 hours of visual loss. Such diagnoses include retinal arterial infarction, venous occlusion, optic nerve head infarction (anterior ischaemic optic neuropathy), haemorrhage, or acute disc swelling. The last may be associated with sudden visual loss in acute papilloedema, or Leber's hereditary optic neuropathy. Visual disturbance with field loss usually confined to an enlarged blind spot can also be seen in diabetic papillopathy, ${ }^{17}{ }^{18}$ or the big blind spot syndrome, ${ }^{219}$ although these conditions more commonly present with minimal visual symptoms. Table 2 lists the various ophthalmoscopic findings seen in each of the above diagnoses.

Table 2 also lists appropriate investigations. Certain points are amplified below.

(1) If there are no abnormalities in the retina, posterior ischaemic optic neuropathy is a possibility, but imaging the orbit would be required to exclude a compressive lesion. Other investigations would be similar to those for anterior ischaemic optic neuropathy (AION). ${ }^{2}$

(2) The investigation of central retinal artery occlusion is similar to that for amaurosis fugax, ${ }^{89}$ although local retinal causes such as radiation retinopathy ${ }^{28}$ may contribute to its aetiology.

(3) In central retinal vein occlusion, search for anticardiolipin antibodies is probably not worthwhile unless the patient has other features of systemic lupus erythematosus. ${ }^{29} 30$

(4) Anterior ischaemic optic neuropathy may be arteritic or non-arteritic. An erythrocyte sedimentation rate is required as an emergency, and, if any other feature suggests temporal arteritis, a temporal artery biopsy should be performed, even if the sedimentation rate is normal (see above). The role of ophthalmic colour Doppler is as yet undetermined, but it may be of use in differentiating arteritic from non-arteritic AION. ${ }^{31}{ }^{32}$ In the absence of clinical features of temporal arteritis or a raised erythrocyte sedimentation rate, biopsy is unlikely to be positive, and is therefore unnecessarily invasive. The exception to this is in bilateral simultaneous AION in which a large proportion of patients have evidence of systemic connective tissue disease. ${ }^{2}$ In younger patients or those with bilateral disease, investigation for coagulation abnormalities is appropriate. ${ }^{24}$ The history may point to one of the rarely-encountered associations between AION and other diseases, ${ }^{2}$ but routine investigation beyond that indicated in table 2 is probably not worthwhile unless it does.

(5) Neuroretinitis is generally thought of as a relatively benign condition in which central visual loss occurs over hours and is associated with a central scotoma and a macular star on ophthalmoscopy. ${ }^{25}{ }^{33}$ However, it may present acutely, and have a poor prognosis. ${ }^{26}$ In this situation, investigation should include tests for vasculitic and infective diseases (particularly 
Table 2 Ophthalmoscopic findings and investigations in acute monocular visual loss

\begin{tabular}{|c|c|c|}
\hline Condition & Ophthalmoscopic findings & Appropriate investigations \\
\hline $\begin{array}{l}\text { Central retinal } \\
\text { artery occlusion }\end{array}$ & $\begin{array}{l}\text { Opacification of nerve fibre layer } \\
\text { Cherry red spot } \\
\text { (Cholesterol) embolus/microemboli } \\
\text { Attenuation of arterial tree }\end{array}$ & $\begin{array}{l}\text { ESR } \\
\text { Fluorescein angiography } \\
\text { (as for amaurosis fugax) } \\
\text { Carotid ultrasound/angiography }\end{array}$ \\
\hline $\begin{array}{l}\text { Central retinal } \\
\text { vein occlusion }\end{array}$ & $\begin{array}{l}\text { Retinal venous dilatation } \\
\text { Scattered retinal haemorrhages (several } \\
\text { disc diameters from optic disc) }\end{array}$ & $\begin{array}{l}\text { FBC, ESR, fibrinogen, glucose } \\
\text { Lipid profile } \\
\text { (fluorescein angiography) } \\
\text { (BP, intraocular pressure) }\end{array}$ \\
\hline AION & $\begin{array}{l}\text { Sectoral/complete optic disc swelling } \\
\text { Disc haemorrhages } \\
\text { Exudates/macular star } \\
(\text { Small optic discs } \\
\left(\text { Buried drusen }^{23}\right)\end{array}$ & $\begin{array}{l}\text { ESR, ? temporal artery biopsy } \\
\text { Fluorescein angiography } \\
\text { FBC, fibrinogen, glucose } \\
\text { Protein electrophoresis } \\
\text { Lipid profile } \\
\left(\text { coagulopathy screen }{ }^{24} \text { ) }\right.\end{array}$ \\
\hline Neuroretinitis ${ }^{25} 26$ & $\begin{array}{l}\text { Disc swelling, peripapillary exudates } \\
\text { Macular star formation } \\
\text { Possibly vitreous cells }{ }^{25}\end{array}$ & $\begin{array}{l}\text { (As for AION) } \\
\text { VDRL, ANA, serum angiotensin converting enzyme } \\
\text { Viral titres, Lyme serology }\end{array}$ \\
\hline $\begin{array}{l}\text { Leber's hereditary } \\
\text { optic neuropathy }\end{array}$ & $\begin{array}{l}\text { Circumpapillary telangiectatic } \\
\text { microangiopathy } \\
\text { (Non-oedematous) elevation of optic disc }\end{array}$ & $\begin{array}{l}\text { Fluorescein angiography } \\
\text { Mitochondrial DNA }\end{array}$ \\
\hline $\begin{array}{l}\text { Infiltrative optic } \\
\text { neuropathy }\end{array}$ & $\begin{array}{l}\text { Optic disc swelling } \\
\text { Haemorrhages/exudates }\end{array}$ & $\begin{array}{l}\text { B mode ultrasonography } \\
\text { MRI/CT, lumbar puncture; chest radiography } \\
\text { Bence-Jones protein } \\
\text { Serum angiotensin converting enzyme } \\
\text { Bone marrow, abdominal CT }\end{array}$ \\
\hline $\begin{array}{l}\text { Diabetic } \\
\text { papillopathy }{ }^{1718}\end{array}$ & $\begin{array}{l}\text { Disc swelling, usually bilateral } \\
\text { Haemorrhages/exudates }\end{array}$ & $\begin{array}{l}\text { Glucose, haemoglobin Alc } \\
\text { Fluorescein angiography }\end{array}$ \\
\hline $\begin{array}{l}\text { Big blind spot } \\
\text { syndrome }{ }^{219}\end{array}$ & $\begin{array}{l}\text { Swollen optic disc (?absent) } \\
\text { Venous overfilling, occasional haemorrhage } \\
\text { Multiple evanescent white dots }{ }^{27}\end{array}$ & $\begin{array}{l}\text { MRI/CT, lumbar puncture } \\
\text { Fluorescein angiography }\end{array}$ \\
\hline
\end{tabular}

ESR = erythrocyte sedimentation rate; AION = anterior ischaemic optic neuropathy; FBC = full blood count; VDRL = venereal disease research laboratory test; ANA = antinuclear antibody.

cat scratch fever) as well as those tests listed for AION, but in most cases investigation is negative. ${ }^{26}$

(6) In Leber's hereditary optic neuropathy, fluorescein angiography shows peripapillary telangiectasia and an apparently swollen disc which paradoxically does not leak, ${ }^{34}$ although these findings are not always present. ${ }^{35}$ This finding should be followed by mitochondrial DNA analysis. ${ }^{35}$ Interestingly, there may be surprisingly little by way of relative afferent pupillary defect. ${ }^{36}$

(7) Occasionally optic nerve head drusen can present as acute visual loss, often with inferior nasal field defect. ${ }^{23}$ This diagnosis is generally taken to be a diagnosis of exclusion after full investigation in the form of CT/MRI, lumbar puncture, and investigations as for AION. The drusen themselves may be more specifically detected by CT, MRI, fluorescein angiography, or ocular ultrasound. ${ }^{137}$

\section{OPTIC NERVE PATHOLOGY DEVELOPING OVER} HOURS TO DAYS

If a patient presents with the typical history and signs of optic neuritis, standard wisdom has been that there is no need to image the patient, provided there are no clinical features to suggest a diagnosis of multiple sclerosis. ${ }^{3}$ Recently, however, this view has been changed somewhat by two developments. Firstly, the recent optic neuritis trial suggested that patients with typical optic neuritis should be treated with intravenous methyl prednisolone (whatever the severity) as this significantly reduced the likelihood of progressing to diagnosable multiple sclerosis at two years ${ }^{38}$ (although the most recent report from the optic neuritis study group suggests that the two year benefit is not maintained at three years $\left.{ }^{39}\right)$. Secondly, recent studies have sug- gested that the prognosis for going on to develop multiple sclerosis is much less if MRI is otherwise normal than if it shows multiple lesions. ${ }^{40}$ For these reasons, it has been advocated that all cases of typical optic neuritis should have $M R I,{ }^{41}$ but this remains controversial. There is no role for visual evoked potentials, CT, or lumbar puncture in the clinical management of typical isolated optic neuritis.

If any of the features of typical optic neuritis is missing, both optic nerves are affected, there is no evidence of recovery after four weeks, or there are additional features, then further investigation is warranted. In the first instance, it is appropriate to image the orbits, paranasal sinuses, sphenoid, and pituitary fossa to detect compressive lesions (which may have acutely decompensated) or infective processes such as paranasal sinus disease. As a first line investigation, contrast enhanced orbital CT is probably still the investigation of choice, ${ }^{1342}$ but intrinsic and inflammatory optic nerve lesions are better shown on MRI, ${ }^{43}$ and both may be required. Skull radiography is not useful in the investigation of visual loss. ${ }^{44}$ Lumbar puncture is indicated if imaging does not yield a diagnosis.

Previous or concurrent symptoms of infective illness raise the possibility of viral, paraviral, or postviral syndromes, or active bacterial or fungal infection. It is thus worth considering screening blood and CSF for viruses, bacterial infections, and fungal infections as appropriate to the clinical picture. Optic neuritis has been reported in systemic lupus erythematosus, and other immune mediated conditions such as Sjögren's syndrome and ulcerative colitis. ${ }^{12}$ If the optic neuritis is atypical in any way, antinuclear antigen and antidsDNA antibodies, along with extractable 
nuclear antigen should be checked.

Perhaps the most common "lookalike" of optic neuritis is sarcoidosis affecting the optic nerve. Suspicion should be raised by failure of the visual loss to improve, or any evidence of past or present iritis or uveitis. Initial investigation in the form of a chest radiograph, serum angiotensin converting enzyme, and lumbar puncture is appropriate. Unfortunately, Kveim testing is no longer available as a diagnostic test. In the absence of any other clinical features, my experience has been that further tests such as pulmonary function tests or gallium scans are unlikely to be rewarding, but could be considered.

About $20 \%$ of simultaneous bilateral optic neuritis in adults turns out to be due to Leber's hereditary optic neuropathy, even in the absence of affected relatives, ${ }^{45}$ and in this circumstance, mitochondrial DNA analysis should be performed. A further $20 \%$ turn out to be due to multiple sclerosis. ${ }^{45}$ Other possibilities include toxic neuropathy. This could be due to medication the patient is taking, or possibly to an external agent such as lead. Serum lead, B12, and a toxicology screen should be added to the above tests, along with careful questioning of the patient regarding drugs, diet, and work exposure.

\section{OPTIC NERVE PATHOLOGY DEVELOPING OVER DAYS OR MONTHS}

In this situation, imaging is mandatory, and should include good views of the optic nerves (intraorbital, intracanalicular, and intracranial) including the pituitary fossa region. As mentioned, there is some debate as to whether high quality enhanced orbital CT, or gadolinium enhanced MRI is superior as a first line investigation, ${ }^{13}{ }^{42} 43$ but it is not uncommon for both to be required eventually. Practically, it depends on local facilities. Most lesions large enough to cause visual loss by optic nerve compression will be visible, but it is not uncommon for optic nerve sheath meningiomas to be missed: repeated scans may be necessary, and are especially indicated if there is evidence of optic disc swelling or optociliary shunt vessels on fundoscopy. ${ }^{46}$

Further investigation of any lesion found will, of course, depend on the nature of the lesion. Imaging in the form of angiography may be necessary, or it might be appropriate to proceed to biopsy. Likewise, thyroid function tests may be appropriate, but these are often normal in thyroid eye disease; the use of a TRH test considerably improves the diagnostic yield. ${ }^{47}$

If imaging of the optic nerve fails to show a reason for the visual loss, infective and inflammatory causes should be screened for with VDRL, HTLV I titres, serum angiotensin converting enzyme, and autoantibody screen, and consideration should be given to an HIV test. Nutritional optic neuropathy can be screened for by checking folate and B12, in combination with a careful dietary history. Smoking, alcohol, drugs (prescribed, "recreational", or otherwise-for example, methanol) are causes of toxic amblyopia and must be looked for, possibly with the help of a toxicology screen.

If visual field testing suggests a lesion of the optic nerve and there is disc swelling on fundoscopy, further thought is required. Papilloedema (disc swelling due to raised intracranial pressure) does not typically cause central visual field loss. Therefore, if there is raised intracranial pressure, this must be due to a structural cause which is associated with optic nerve disease/compression, but imaging should already have detected such a cause. If imaging is normal and the discs are swollen, the next test should be a lumbar puncture. In this circumstance, raised pressure should not be regarded as the cause of the visual loss. An alternative cause in the form of inflammatory disease such as sarcoidosis must be considered and investigated as above. Failing this, carcinomatous meningitis or direct optic disc infiltration by haematological malignancy should be considered, and investigated appropriately.

Hereditary optic neuropathies may be diagnosed on the basis of a positive family history, but occasionally one can be surprised by the way Leber's hereditary optic neuropathy presents, and searching for the known mitochondrial DNA mutations is worthwhile at this point. $^{35}$

Two other reasons for progressive anterior pathway visual failure may have to be considered. Dysplasia of the optic disc may be associated with visual field disturbance. This is often longstanding, but occasionally comes to the attention of the patient and requires explanation. Typical examples include tilted optic discs, which are usually associated with superotemporal field loss, ${ }^{2}$ or optic nerve head drusen (hyaline bodies). ${ }^{48}$ Diagnosis of the second is suggested by anomalous optic disc vasculature, and can be difficult, particularly if the drusen are buried. Help may be required in the form of fluorescein angiography (looking for autofluorescence), or B mode ultrasonography. ${ }^{1337}$ Occasionally calcification of the optic nerve head can be seen on unenhanced CT. ${ }^{13} 37$

Finally, it is not unheard of for a neurologist or neuro-ophthalmologist to be referred a patient who actually has an ophthalmological diagnosis, even if the source of referral is an ophthalmologist. The most common situation in which this arises is that of a maculopathy being misdiagnosed as possible optic nerve disease. It is always worth re-examining the ocular fundus in the case of monocular visual disturbance, particularly if there is no associated relative afferent pupillary defect, so as not to be led into inappropriate investigations.

\footnotetext{
1 Zeki S. A vision of the brain. Oxford: Blackwell, 1993.

Miller NR. Walsh and Hoyt's clinical neuro-ophthalmology. 4th ed. Vol 1. Baltimore: Williams and Wilkins, 1982. 3 Glaser JS. Clinical neuro-ophthalmology. 2nd ed. Philadelphia: JB Lippincott, 1991.

4 Miller NR. Walsh and Hoyt's clinical neuro-ophthalmology 4th ed. Vol 5, part 2. Baltimore: Williams and Wilkins, 1985:4541-63.

5 Acheson JF, Sanders MD. Vision. $f$ Neurol Neurosurg Psychiatry 1995;59:4-15.

6 Keltner JC, Johnson CA, Spurr JO, Beck RW, Optic Neuritis Study Group. Baseline visual field profile of optic neuritis. The experience of the optic neuritis treat-
} ment trial. Arch Ophthalmol 1993;111:231-4. 
7 O'Connell JEA, du Boulay EPGH. Binasal hemianopia. $\mathcal{f}$ Neurol Neurosurg Psychiatry 1973;36:697-709.

8 Hankey GJ, Warlow CP. Cost-effective investigation of patients with suspected transient ischaemic attacks. Neurol Neurosurg Psychiatry 1992;55:171-6.

9 Hankey GJ, Warlow CP. Major problems in neurology 27: transient ischaemic attacks of the brain and eye. London: WB Saunders, 1994.

10 Jacobson DM, Slamovits TL. Erythrocyte sedimentation rate and its relationship to hematocrit in giant cell arteritis. Arch Ophthalmol 1987;105:965-7.

11 Tippin J, Corbett J, Kerber RE, Schroeder E, Thompson HS. Amaurosis fugax and ocular infarction in adolescents and young adults. Ann Neurol 1989;26:69-77.

12 Burde RM, Savino PJ, Trobe JD. Clinical decisions in neuroophthalmology. 2nd ed. St Louis: Mosby Year Book, 1992.

13 Moseley IF. Diagnostic imaging in visual loss: a problemoriented approach. Imaging 1992;4:151-6.

14 Perkin GD. Cerebral venous thrombosis: developments in imaging and treatment. $\mathcal{F}$ Neurol Neurosurg Psychiatry 1995;59:1-3

15 Armington JC. Electroretinography. In: Aminoff MJ, ed. Electrodiagnosis in clinical neurology. New York: Churchil Livingstone, 1992:433-66.

16 O'Sullivan E, Shaunak S, Simcock P, Matthews T, Wade J, Kennard C. Transient monocular blindness. F Neurol Neurosurg Psychiatry 1995;59:559.

17 Barr CC, Glaser JS, Blankenship G. Acute disc swelling in juvenile diabetes: clinical profile and natural history of 12 cases. Arch Ophthalmol 1980;98:2185-92.

18 Pavan PR, Aiello LM, Wafai MZ, Briones JC, Sebastyen JC, Bradbury MJ. Optic disc edema in juvenile-onset diabetes. Arch Ophthalmol 1980;98:2185-92.

19 Fletcher WA, Imes RK, Goodman D, Hoyt WF. Acute idiopathic blind spot enlargement: a big blind spot syndrome without optic disc edema. Arch Ophthalmo 1988;106:44-9.

20 Dodson PM, Kritzinger EE. Management of retinal vein occlusion. BMF 1987;295:1434-5.

21 Walters RF, Spalton DJ. Central retinal vein occlusion in people aged 40 years or less: a review of 17 patients. $B r f$ Ophthalmol 1990;74:30-5.

22 Beck RW, Servais GE, Hayreh SS. Acute ischaemic optic neuropathy. IX. Cup-disc ratio and its role in the pathogenesis of acute ischaemic optic neuropathy. Ophthalmology 1987;94:1503-8.

23 Beck RW, Corbett J, Thompson HS, Sergott RC. Decreased visual acuity from optic disc drusen. Arch Decreased visual acuity from

24 Acheson JF, Saunders MD. Coagulation abnormalities in ischaemic optic neuropathy. Eye 1994;8:89-92.

25 Maitland CG, Miller NR. Neuroretinitis. Arch Ophthalmo 1984;102:1146-50.

26 Purvin VA, Chioran G. Recurrent neuroretinitis. Arch Ophthalmol 1994;112:365-71.

27 Kimmell AS, Folk JC, Thompson HS. The multiple evanescent white dot syndrome with acute blind spot enlargement. Am $\mathcal{f}$ Ophthalmol 1989;107:425-6.

28 Noble KG. Central retinal artery occlusion: the presenting sign in radiation retinopathy. Arch Ophthalmol 1994; 112:1409-10.
29 Merry P, Acheson JF, Asherson RA, Hughes GRV. Management of retinal vein occlusion. BMF 1988, 296:294.

30 Glacet-Bernard A, Bayam N, Chretien P, Cochard C, Lelong F, Coscas G. Antiphospholipid antibodies in retinal vascular occlusion. A prospective study of 75 patients. Arch Ophthalmol 1994;112:790-5.

31 Ho AC, Sergott RC, Regillo CD, et al. Color Dopple hemodynamics of giant cell arteritis. Arch Ophthalmol 1994;112:938-945.

32 Williamson TH, Harris A. Ocular blood flow measurement. Br f Ophthalmol 1994;78:939-45.

33 Bos PJM, Deutman AF. Acute macular neuroretinopathy. Am $\mathcal{F}$ Ophthalmol 1975;80:573-84.

34 Smith JL, Hoyt WF, Susac JO. Ocular fundus in acute Leber optic neuropathy. Arch Ophthalmol 1973;90: 349-54.

35 Riordan-Eva P, Sanders MD, Govan GG, Sweeney MG, Da Costa J, Harding AE. The clinical features of Leber's hereditary optic neuropathy defined by the presence of a pathogenic mitochondrial DNA mutation. Brain 1995; 118:319-37

36 Wakakura M, Yokoe J. Evidence for preserved direct pupillary light response in Leber's hereditary optic neuropathy. Br f Ophthalmol 1995;79:442-6.

37 Kheterpal S, Good PA, Beale DJ, Kritzinger EE. Imaging of optic disc drusen: a comparative study. Eye 1995;9: 67-9.

38 Beck RW, Cleary PA, Trobe JD, Kaufman DI, Kupersmith MJ, Paty DW, Brown CH, and the Optic Neuritis Study Group. The effect of corticosteroids for acute optic neuritis on the subsequent development of multiple sclerosis. tis on the subsequent development

39 Beck RW. The optic neuritis treatment trial: three year follow up results. Arch Ophthalmol 1995;113:136-7.

40 Morrissey SP, Miller DH, Kendall BE, et al. The significance of brain magnetic resonance imaging abnormalities at presentation with clinically isolated syndromes suggestive of multiple sclerosis. A 5-year follow-up study. Brain 1993;116:135-46.

41 Wray SH. Optic neuritis: guidelines. Curr Opin Neurol 1995;8:72-6.

42 Castillo M. Neuroradiology companion. Methods, guidelines and imaging fundamentals. Philadelphia: JB Lippincott, 1995.

43 Moseley I. Imaging the adult brain. $f$ Neurol Neurosurg Psychiatry 1995;58:7-21.

44 Moseley IF. The plain radiograph in ophthalmology: a wasteful and potentially dangerous anachronism. If Roy Soc Med 1991:84:76-80.

45 Morrissey SP, Borruat FX, Miller DH, et al. Bilateral simultaneous optic neuropathy in adults: clinical, imaging, serological and genetic studies. $\mathcal{F}$ Neurol Neurosurg Psychiatry 1995;58:70-4.

46 Sibony PA, Krauss HR, Kennerdell JS, et al. Optic nerve sheath meningiomas: clinical manifestations. Ophthalmology 1984;91:1313-26.

47 Spector RH, Carlisle JA. Minimal thyroid ophthalmopathy. Neurology 1987;37:1803-8.

48 Savino PJ, Glaser JS, Rosenberg MA. A clinical analysis of pseudopapilledema II. Visual field defects. Arch Ophthalmol 1979;97:71-5. 